\title{
Leadership Style and Business Success: Case Studies of Chinese Business Leaders
}

\author{
Xingying Pan ${ }^{1, *}, \dagger$, Xuechen Qiu $^{2, *, \dagger}$, Yifan Zhou ${ }^{3, *, \dagger}$ \\ ${ }^{1}$ College of mathematics and physics, Shanghai Normal University, 201314, China \\ ${ }^{2}$ Wenzheng College, Soochow University, 215204, China \\ ${ }^{3}$ Faculty of Arts and Science, University of Toronto, M5S 1A1, Canada \\ *Corresponding author.Email: Gretchende@163.com,2272740664@qq.com,dina.zhou@mail.utoronto.ca \\ These authors contributed equally.
}

\begin{abstract}
Business leadership plays an increasingly significant role in contributing to the success of a corporate. Nevertheless, leadership performance is problematic in the contemporary business management world. This study, in line with extant leadership style models, sets out to investigate what types of leadership styles are vital for business organizations nowadays. By conducting three successful leadership style case studies on Ma Yun, Dong Mingzhu, and Zhang Yiming, it was found that different industries call for distinct leadership styles and traits. More specifically, in both traditional and online retailing sectors, decisive and authoritarian leadership styles are important. While for those technologydriven companies, the democratic style, insightful perception, and technical skills of the leaders are more essential. The results of the study contribute to the leadership and leadership style research. In the end, based on the research findings, suggestions for ensuing leadership education are also proposed.
\end{abstract}

Keywords: Leadership study, Leadership style, Leadership traits, Chinese business leaders

\section{INTRODUCTION}

Most people believe that those who can lead and influence others are called leaders. To be more specific, a leader is a person who is selected from a group of people and is considered to be the best [1]. However, according to various recent news in China, the leaders seem to be much less majestic than before.

This year, a male employee reported unequal treatment he suffered in the company on the internet. The reason was that his performance was not as expected, so the company's leader burned his face with a cigarette. Not long ago, a female employee was repeatedly assaulted by her leader. This became the focus of the news and has also aroused the concern of many netizens. Although the female employee had repeatedly reflected the matter to the company's management office, most of the leaders chose to avoid the problem. The most ironic thing is that this female employee came from the famous Chinese technology company Alibaba. Considering such a big company can have such an unethical leader, it can be seen that most of the company's standards for the selection of leaders have dropped significantly.
In fact, the above news can also reflect from the side that their leaders in the workplace have bullied both male and female employees. But for any business, having strong leadership has become indispensable. Good leaders are important to the future of a business [2], and as former U.S. Secretary of State Henry Kissinger said, "The task of the leader is to get his people from where they are to where they have not been."

Therefore, for the above phenomena of employees being bullied by their leaders, this research paper will study what kind of leaders are preferred by employees in large companies in China by comparing them from different scales. As a famous psychologist, $\mathrm{K}$. Lewyn has already classified leadership styles into three categories: authoritarian style (power is concentrated in the individual leader), democratic style (all participate in the decision-making process), and delegative style (each employee does his or her own thing) [3]. Therefore, the article will also analyze the leadership styles of three famous leaders of large Chinese companies. More specifically, Dong Mingzhu, Ma Yun, and Zhang Yiming are selected as research objectives. 
It is easy for us to find that the leaders of different companies have their own personality characteristics and behavior styles. Therefore, we will use three leaders as examples to classify and analyze different personalities and styles. Stephen A. Miles and Michael D. Watkins have published an article, The Leadership Team: Complementary Strengths or Conflicting Agendas? Discussing the complementarity or conflict of the leadership team. It is believed that it is necessary to analyze the leaders' abilities to be more persuasive according to different situations in different companies. Therefore, our classification and comparison would be more conducive to providing targeted suggestions for the training and education of future leaders and can consciously develop leaders with more matching personality styles into more suitable positions.

\section{CASES INTRODUCTION}

As aforementioned, this paper aims to analyze the characteristics of leaders that employees more prefer by analyzing the behavior style and personality of three famous leaders in large enterprises in China. Their introduction is demonstrated in Table 1 below.

Table 1. Introduction of the selected leaders

\begin{tabular}{|c|c|c|}
\hline Leader & Gender & Birth Main Achievements \\
\hline $\begin{array}{l}\text { Dong } \\
\text { Mingzhu }\end{array}$ & Female & 1954100 best CEOs in the world \\
\hline \multicolumn{3}{|r|}{ 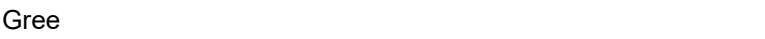 } \\
\hline \multirow[t]{2}{*}{ Electric. } & & $\begin{array}{l}\text { No. } 1 \text { in } 2017 \text { ranking of China's most } \\
\text { outstanding businesswomen }\end{array}$ \\
\hline & & $\begin{array}{l}\text { Won the "Ishikawa Shino hunting wild } \\
\text { Award" organized by Asian quality } \\
\text { network }\end{array}$ \\
\hline \multirow[t]{2}{*}{ Jack Ma } & Male & 1964 Alibaba Group was founded in 1999 \\
\hline & & $\begin{array}{l}\text { The 10th Japanese Entrepreneur Award } \\
\text { in } 2008\end{array}$ \\
\hline \multicolumn{3}{|l|}{ Alibaba } \\
\hline \multirow[t]{2}{*}{ Group } & & $\begin{array}{l}\text { Business leaders of China's economic } \\
\text { decade in } 2009\end{array}$ \\
\hline & & $\begin{array}{l}2012 \text { CCTV China economic person of } \\
\text { the year }\end{array}$ \\
\hline Yiming & Male & 1983 No. 10 of Forbes China rich list in 2019 \\
\hline \multirow{3}{*}{$\begin{array}{l}\text { Byte } \\
\text { Dance }\end{array}$} & & 2019 China economic news figures \\
\hline & & $\begin{array}{l}\text { China's } 50 \text { most influential business } \\
\text { leaders in } 2020\end{array}$ \\
\hline & & $\begin{array}{l}\text { Founded Beijing byte Beating } \\
\text { Technology Co., Ltd }\end{array}$ \\
\hline
\end{tabular}

Respectively, their leadership styles are classified based on the Myers Briggs Type Indicator (MBTI) model through a narrative analysis of their leadership styles and traits [4]. Finally, some implications are put forward in the conclusion section to shed light on future business leadership studies.

\section{CASES ANALYSIS}

\subsection{Dong Mingzhu and Gree}

Dong Mingzhu, as the leader of Gree Electric, is an ordinary person who has worked through herself step by step and thus got to where she is today. According to her background, she has neither the prestigious school background nor the illustrious family background of other leaders, nor the beautiful appearance nor the rich husband. Still, she has created the myth of Chinese women and become the title of Chinese corporate woman of the moment.

In fact, Dong Mingzhu was just a saleswoman at the beginning of her career because her husband left, forcing her to work hard to earn tuition for her son, perhaps because of the pressure of life over the years coupled with their own eloquent sales eloquence. Eventually, she became an indispensable part of the company. In fact, the initial occupation of Dong Mingzhu was just a saleswoman. Although it was not a great job, she was also one of the best performers at the time.

Since there are cases in the news that some leaders use their positions to bully employees (e.g., sexual assault), it is imperative to know what employees in China prefer types of leaders. First, analyze Dong Mingzhu's personality as a person from the perspective of MBTI. Dong is a typical MBTI personality type of ESTJ management type. ESTJ type people have a high efficiency working state and a sense of responsibility at the same time, and they can make and follow the rules, prefer to work in a place with a sound system, and prefer a pragmatic business with a focus on tangible products. In fact, the fact that Dong Mingzhu insists on working in Gree, a manufacturing company, proves that she is a pragmatic and patriotic person.

She is also very concerned about the staff. Dong Mingzhu, in a public lecture, to share the management of the company, told a story about dealing with an employee being beaten. The general content is that the products provided by the supplier have problems, their own company employees asked to return the goods. Still, unexpectedly the supplier found someone to beat their own staff. For this matter, Dong Mingzhu first dismissed the leadership of the beaten employees and announced never to cooperate with this supplier. Dong Mingzhu's action gave her staff great support and encouragement, as employees will take this matter to heart, do not regret that they came to Gree Electric.

What is actually a good leader? The one who thinks about her employees is the leader that employees like. Nowadays, many young people seek to start their own business, but how many companies have really made 
their business famous? Most young people are always pointing fingers at their own staff, cracking down on staff motivation, often reprimanding employees. How can this make the company grow? Dong Mingzhu herself is used to be a small staff. She understands the bottom of the people's pain, so when she became a leader, she still put the interests of the staff in the front. Perhaps this is the reason she can become a good leader [5].

Although Dong Mingzhu is from the sales, she can best understand that the staff is not easy, so she continues to give employees processing wages and shareholders dividends. But some employees do not like Dong Mingzhu, and the reason is that she is not smooth enough for employees. The talk will not be cornered, not the Chinese golden mean. Perhaps it is too bitter at the beginning of her career. Dong Mingzhu was forced into a female leader who spoke harshly, thus leading to employees being afraid to approach her.

So, what kind of leaders do employees in China like? Is it a leader who has worked hard from the bottom to get to where they are today and can understand the employees' pain? Or is it a leader with a distinguished family and a gentle personality who can talk about life with his employees?

Since Dong Mingzhu's leadership characteristics have been analyzed through the MBTI personality test, this research paper will analyze in detail the famous Chinese leaders in the e-commerce and Internet industries through the MBTI test theory.

\subsection{Ma Yun and Alibaba}

Alibaba Group Holding Co., Ltd. (hereinafter referred to as Alibaba Group) was founded in Hangzhou, Zhejiang Province, in 1999 by 18 people led by Jack Ma, a former English teacher.

Alibaba Group operates a number of businesses. In addition, it also obtains business ecosystem support from the businesses and services of affiliated companies. The business and business of affiliated companies include Taobao, small, cost-effective, global express, Alibaba international trading market, 1688, Alibaba mother, Alibaba cloud, and financial services, rookie network, etc.

According to the theoretical model of the MBTI career discovery test, Jack Ma can be a typical ENFJ type, an instructional personality, E-extroversion, N-essence, F-feeling, and J-Judging. These types of people are enthusiastic, considerate, sociable, and responsible. They tend to pay great attention to the feelings, needs, and motives of others, be good at discovering the potential of others, are willing to help them realize, and are willing to become a catalyst for the growth and progress of individuals or groups. Therefore, this kind of character can help others well in the group and has the leadership ability to inspire others. Let's take a look at it in detail below:

Extroversion: In 1988, Jack Ma graduated from the English major of the Department of foreign languages of Hangzhou Normal University and entered the University as a lecturer in English and international trade. After that, Jack Ma became an excellent young teacher in Hangzhou, launched the first English corner near the West Lake, and became famous in the translation circle in Hangzhou. In 1992, because many people came to ask Jack Ma to do translation, Jack Ma established Haibo's translation agency and asked retired teachers to do the translation. To survive, Jack Ma went to Yiwu and Guangzhou to buy goods with sacks on his back. Haibo's translation agency began to sell flowers and gifts and once sold medicine for a year, from big hospitals to rural doctors. In 1994, the revenue of the Haibo translation agency was flat. Among them, bill, a foreign teacher from Seattle, talked to Jack Ma about the Internet. Jack Ma began to look for opportunities and decided to start a business. In early 1995, the Haibo translation agency began to make money. Jack Ma came to Los Angeles as a translator to communicate and implement an unsuccessful expressway investment. Fly from Los Angeles to Seattle to find the bill. Bill takes Jack Ma to visit VBN, the first ISP company in Seattle. From the above situation, Jack Ma tends to have an E-type personality and likes social networking and public utilities [7].

Intuition: Jack Ma showed more of his intuition in his career. His keen intuition decided many major events in his life. When I was a child, the geography teacher encouraged the students in class: "students, you must learn geography well, otherwise when people ask us, if you can't answer, it will humiliate the Chinese people!" Listening to Jack Ma's ears, the intuitive association and inspiration are that we must learn English well and have a bright future in the future. After geography class, when he came home from school, he went to the canteen to buy a pocket radio, practiced English hard, and finally became the "first person in Hangzhou English". When Jack Ma taught in the University, from his own work experience, he found the huge demand for English talents and translation business in the society. He predicted that this would be a great potential market in the future. As early as 1992, he established Haibo's translation agency, the first professional translation agency in Hangzhou, and now it has become the largest professional translation agency in Hangzhou. In 1995, Jack Ma contacted the Internet for the first time in the United States and found that he could not find any information about China on the magical Internet. He was shocked and incredible. His keen intuition told him: "I feel that it will certainly affect the whole world, but China has not yet." an idea flashed in Jack Ma's mind: go back to China to start a business and do the Internet! He is used to following his intuition about the future trend of the Internet. 
Feeling: One day, when he went to work by bike, he saw five or six people carrying manhole covers along the road. It seemed that they were going to steal and sell them. Jack Ma thought of the newspaper reports a few days ago that a child fell into an uncovered manhole and drowned, so he thought of stopping it. But he was worried about "how can I beat five or six people", so he rode four or five hundred meters away to find help. Unexpectedly, no police were found, and no one else was willing to help. "I walked around twice and saw that they were still lifting. I really couldn't help it." Jack Ma said with a smile that he stepped on the ground and on the bicycle pedal and was ready to run away at any time. Then he pointed to the other party and shouted, "you carry it back".

At that time, Jack Ma found that someone had stolen the manhole cover. There were five or six people, but he couldn't beat them. He then ran four times to the police, to no avail. Finally, he couldn't help but decided to stop each other by himself. This is a process in which sensibility is greater than rationality.

He tends to persevere and work hard for a goal, which shows that he is judgmental (J). He is tenacious. In the process of starting a business, he has encountered countless difficulties. He is almost unable to set up a company due to a lack of funds. Although he has made great achievements in previous startups, he has to leave for various reasons. Nevertheless, he never gives up and continues to work hard. When it is difficult, he should know how to warm his right hand with his left hand. Jack Ma has strong autonomy and independence. He will not hesitate to decide things. Once identified, he will firmly believe in his judgment and stick to it [8].

For ENFJ-type people, the most important thing is interpersonal relationships and opportunities to communicate with others. ENFJ people have a strong leadership temperament and extraordinary ability to manipulate others. We can see these characteristics from Jack Ma. ENFJ people believe in their dreams and regard themselves as rescuers and capable people, and often they do. Jack Ma's dreams were not understood, but they shocked the world with their dreams come true [4].

\subsection{Zhang Yiming and Bytedance}

ByteDance is a technology company with global influence. This is the same as other Internet companies, including education and extensive online services, including education, games, payment, etc. Toutiao, Douyin, and TikTok are the core driving forces of Bytedance. In the early days of these businesses, it was discovered that the direct tone program had developed differently, and it is a young and lightweight application that matches. However, the product and technology of the stage are beyond. Today's Toutiao is the development and application of today's application information. The success of Douyin depends on the professional knowledge of operations and the cash reserves of Toutiao. The success of TikTok is based on the product experience of Douyin, and all strategies should be adopted for successful promotion. Zhang's foresight and decisive decision-making [9].

According to the theoretical model of the MBTI career discovery test, Yiming can be a typical ENTP type, a very standard inventor personality, E-extroversion, Nessence, T-thinking, and P-discovery. For this type of people, the most important thing is to have children, to be able to easily reach a bright future and to have time. This is very suitable for the Internet industry that requires brainstorming and random games. Let's take a look at it in detail below:

Outgoing: Zhang Yiming met many excellent partners in college. Even if he doesn't love friendship, he cherishes friendship. Whether it is or not, I have been invited by the old people of the company. These experiences have also created a solid foundation for my friends to thrive. Extroversion may also refer to the initiative in terms of jetting, and there is no fixed pattern for the occurrence of all things in the world. This was fully discovered when Zhang Yiming worked at Microsoft Research Asia in 2008. When Zhang Yiming looked back at him at Microsoft, he admitted that it was the most boring year of his career. In a large company with a slow pace and rules everywhere, this kind of culture shock made him feel that he often had nothing to do.

Intuition: Willing to be willing, like new problems. At the beginning of 2011, Zhang Yiming reminded most people that they used smartphones and discovered later information. Spread, mobile phones are likely to attract paper-based information dissemination carriers. The personalized demand for mobile phones will definitely increase because of the relationship between people and mobile phones. Zhang Yiming's observations are very accurate, and he has judged the development goals of mobile phones. Therefore, Zhang Yiming has doubled down on mobile development, resigned from the real estate industry under long-term returns, and obtained the opportunity of mobile intelligent Internet thinking. The business sense of smell shows the keenness he needs.

Thinking: Use a logical process to make decisions. In the 2008 issue of China, 2020, Zhang Yi believes that perseverance, perseverance, and judgment are based on long-term thinking and not interfered with by short-term factors. Patiently waiting for you and working hard to gradually notify the office is very important for entrepreneurship. Zhang Yiming has always been a person who thinks about problems with logic and thinking. When he bought his first apartment in Beijing, he did not consult an intermediary or consult with his family. Still, he made an electronic form by himself, made one by himself, and analyzed the data obtained from the online search data. The browsing engine is a portal network, followed by search, then blog, and now a 
recommendation engine. These are different ways of sending and receiving information, and we can see the effects of technologies that are not available. Zhang Yiming's preliminary framework has detailed the timing of the Internet information release method of the era.

Perception: Zhang Yiming paid more attention to his appearance and changed his usual dressing habits in the hive. Now his clothes are opened, and he is also very formal. Toutou, Tiaoyin, Watermelon Video, Scissors, Feishu, Diaoche, and many other applications, including overseas TikTok, Vigo, TopBuzz, FaceU, and so on. The story of ByteDance continues, and Zhang Yiming's leadership will continue to influence the discussion of leadership styles.

\section{CONCLUSION}

To sum up, through the analysis of these three famous Chinese leaders, it can be found that leaders with different personalities are needed in different industries. For ordinary people, only to find their own areas of expertise to play their role. For the industry in the future, finding suitable leaders will be more conducive to the tonality and development of the industry, thus improving efficiency and giving full play to leadership.

\section{REFERENCES}

[1] Winston, B. E., \& Patterson, K. (2006). An integrative definition of leadership. International journal of leadership studies, 1(2), 6-66.

[2] Summerfield, M. R. (2014). Leadership: A simple definition. American Journal of Health-System Pharmacy, 71(3), 251-253.

[3] Lewin, K. (1944). A research approach to leadership problems. The Journal of Educational Sociology, 17(7), 392-398.

[4] Boyle, G. J. (1995). Myers-Briggs type indicator (MBTI): some psychometric limitations. Australian Psychologist, 30(1), 71-74.

[5] Tonks, A. (2007). The leadership team: Complementary strengths or conflicting agendas? Harvard Business Review, 85(7-8), 186-186.

[6] McDonald, P. (2011). Maoism versus Confucianism: Ideological influences on Chinese business leaders. Journal of Management Development.

[7] Toma, S. G., Marinescu, P., Constantin, I., \& Costea, D. (2019). Beyond charismatic leadership: The case of Jack Ma. Manager, (29), 99-105.

[8] Bo, T., \& Chan, V. (2018). Jack Ma's leadership style as a key to Alibaba commercial success. Section 1 Globalized Economy: Challenges and Prospects, 200.
[9] Ma, Y., \& Hu, Y. (2021). Business model innovation and experimentation in transforming economies: ByteDance and TikTok. Management and Organization Review, 17(2), 382-388. 